\title{
Insulin ved intensivbehandling av barn?
}

\author{
Insulinbehandling for å holde blod-glukosenivået lavt gir ikke lavere \\ overlevelse eller færre respiratordøgn hos barn i intensivavdeling.
}

Insulinbehandling av voksne nyopererte intensivpasienter uten diabetes for at blod-glukosenivået i blodet skal holdes lavt, er i enkelte studier vist å gi høyere overlevelse og mildere

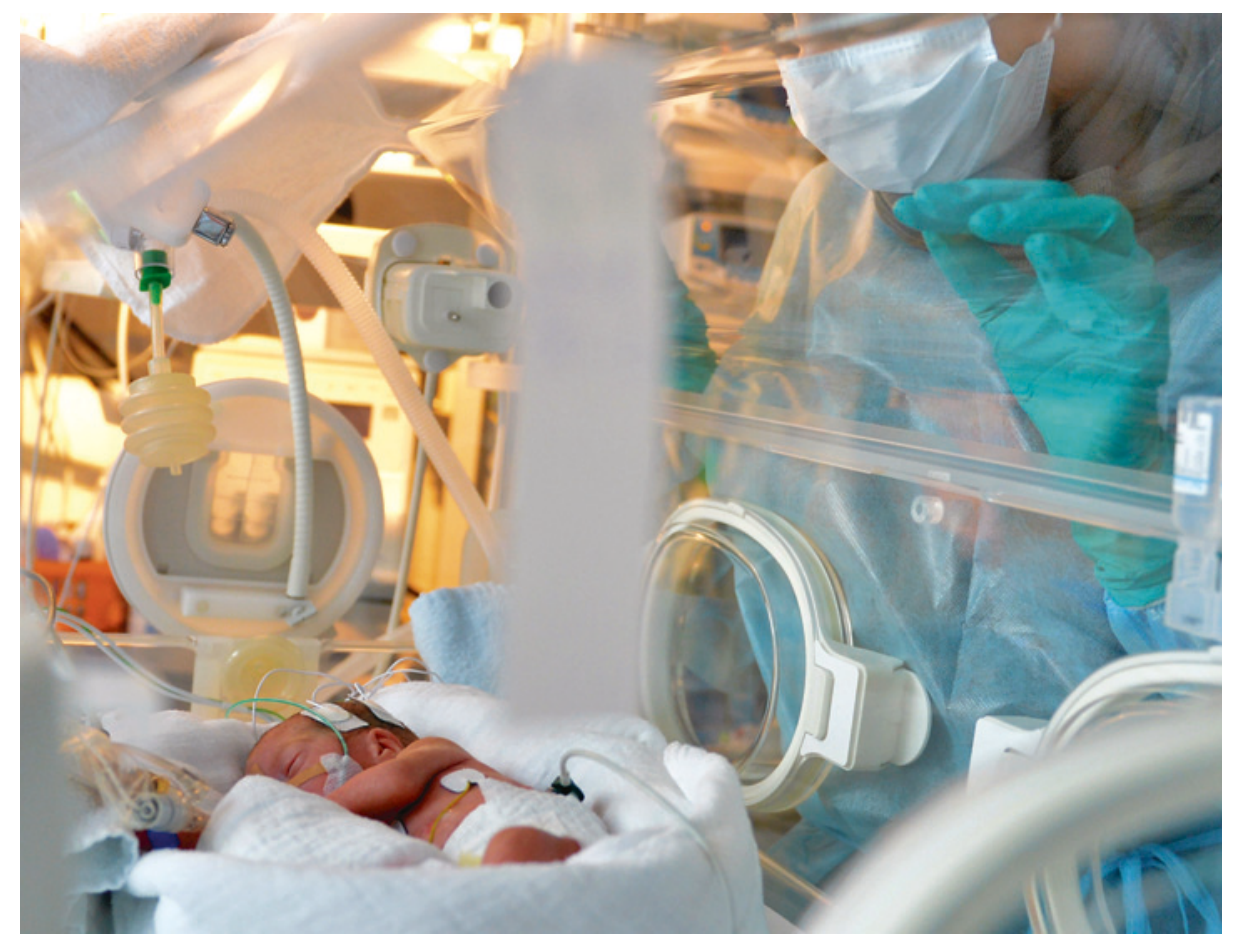

Illustrasjonsfoto @ DPA/NTB scanpix

\section{Kognitiv atferdsterapi ved bulimi}

\section{Kognitivatferdsterapi er bedre enn psykoanalytisk orientert behand- \\ ling ved bulimia nervosa.}

I en fersk studie fra det psykoanalytiske fagmiljøet ved Københavns Universitet ble 70 pasienter med bulimia nervosa randomisert til enten 20 timer med kognitiv atferdsterapi i fem måneder eller til to år med ukentlig psykoanalytisk orientert terapi.

Begge terapiformene hadde effekt, men kognitiv terapi ga raskest og best respons. Rett etter at terapiperioden var over, hadde $42 \%$ av pasientene i denne gruppen sluttet med overspising og brekninger, mot $6 \%$ i den andre gruppen. Etter to år hadde $44 \%$ i gruppen som fikk kognitiv terapi og $15 \%$ av dem sykdomsforløp. Nylig er en tilsvarende studie med barn gjennomført (1).

Noe over 1300 barn fra nyfødtalder (unntatt premature) til 16 år som var under intensiv- behandling med vasoaktive medikamenter og i respirator i minst 12 timer ble randomisert i to grupper. I den ene gruppen ble glukosenivået regulert til å være innenfor $4-7 \mathrm{mmol} / \mathrm{l}$, mens den andre gruppen kun fikk insulinbehandling hvis glukosenivået gikk over $12 \mathrm{mmol} / \mathrm{l}$.

Det var ingen forskjeller mellom gruppene i overlevelse eller respiratorbehandlingstid. Hypoglykemi forekom hyppigere i gruppen med lavt blodsukkermål, særlig hos dem som fikk insulin. Behandlingskostnadene for sykehusoppholdet det påfølgende året var lavest $i$ gruppen med strengest glukoseregulering.

- Generelt er dødeligheten i pediatriske intensivavdelinger lav. Det er derfor ingen overraskelse at man i denne studien ikke fant noen forskjell i overlevelse, som er et svært grovt mål, sier overlege Jon Henrik Laake ved Intensivavdelingen, Oslo universitetssykehus, Rikshospitalet. - Målsettingen om så streng kontroll av blod-glukosenivået må sies å være urealistisk uten en gjennomarbeidet og etablert algoritme for insulinbehandling. Sannsynligheten for at alle sentrene i denne multisenterstudien har like gode rutiner er liten, sier Laake.

\section{Paal H.H. Lindenskov}

Overlege ved Akuttklinikken, Avdeling for anestesiologi, Oslo universitetssykehus, Rikshospitalet

\section{Litteratur}

1. Macrae D, Grieve R, Allen E et al. A randomized trial of hyperglycemic control in pediatric intensive care. N Engl J Med 2014; 370: 107-18 som fikk psykoanalytisk psykoterapi oppnådd det samme (oddsratio 4,3; $95 \% \mathrm{KI}$ 1,33-14,21). I begge gruppene var det bedring i symptomer knyttet til spiseforstyrrelsen og generelle psykiske plager, men effekten kom tidligst etter kognitiv atferdsterapi.

- Det er en utbredt oppfatning i fagmiljøet at type samtaleterapi ikke er avgjørende for effekten, sier Terje Fladvad, privatpraktiserende psykiater i Oslo. - Denne studien viser det motsatte. Kognitiv terapi kom klart best ut, til tross for betydelig mindre ressursbruk. Det er også verdt å merke seg at de psykoanalytiske terapeutene var langt mer erfarne enn de kognitive terapeutene, sier han.

- Det er sjelden at en studie i så stor grad går i disfavør av den terapien gruppen som har gjort den er eksperter på. Samtidig er det prisverdig at studien blir publisert på tross av negativt resultat for gruppen som sto bak.

Resultatene understøtter internasjonale behandlingsanbefalinger for bulimia nervosa, der kognitiv atferdsterapi er anbefalt førstevalg. Denne behandlingsmetoden bør bli mer tilgjengelig for pasienter med bulimia nervosa og liknende spiseforstyrrelser, sier Fladvad.

\section{Kari Tveito}

Tidsskriftet

\section{Litteratur}

1. Poulsen S, Lunn S, Daniel SI et al. A randomized controlled trial of psychoanalytic psychotherapy or cognitive-behavioral therapy for bulimia nervosa. Am J Psychiatry 2014; 171: 109-16. 